\title{
Synthesis and Light-Emitting Behavior of Silicon-Bridged Fluorene Copolymers Bearing Oligoarylenevinylene Chromophore
}

\author{
By Koji TAKAGI, ${ }^{*}$ Ai TAHARA, and Hiroki KAKIUCHI
}

\begin{abstract}
Silicon-bridged fluorene copolymers bearing oligoarylenevinylene chromophore with longer effective conjugation length than terfluorene were prepared by the Suzuki coupling copolymerization, where the polymer structure was designed so that the absorption spectrum of energy-accepting oligoarylenevinylene chromophore can overlap with the emission spectrum of energy-donating terfluorene chromophore. The content of oligoarylenevinylene segment in 2a5, 2a10, 2a20, 2a48, and 2a100 could be well controlled by the monomer feed ratio as evidenced by the UV spectra of copolymers in solution. Since the fluorescence from oligoarylenevinylene segment was observed in copolymers and the polymer blend system did not afford longer wavelength emission in dilute solution, the importance of intra-polymer chain energy transfer between chromophores was demonstrated. The fluorescence peaks of $\mathbf{2 b 1 3}, \mathbf{2 c 1 1}$, and $\mathbf{2 d 3}$ ascribed to the emission from oligoarylenevinylene segment were observed in thin film through the intra- and inter-polymer chain energy transfer.
\end{abstract}

KEY WORDS: Silicon / Fluorene / Copolymer / Energy Transfer / Light-Emission /

Conjugated polymers are applicable to many optoelectronic devices such as light-emitting diode, photovoltaic cell, fieldeffect transistor, fluorescent sensor, and so on. Polymer materials have merit over low molecular weight counterparts in that thin film with superior mechanical flexibility can be obtained by cost-effective printing processes, which enable the realization of ubiquitous products. On the other hand, polymers are the mixture of many chains having various length, namely, the concentration of terminal group differs one by one. The chain length and terminal group of conjugated polymer significantly influence optoelectronic properties of material, however, their fine control is still the matter of argument. ${ }^{1}$ In addition, the structure defects contaminated in polymer backbone are difficult to be removed by the purification technique to decrease the quality of material. These problems often result in the poor color purity and/or the short lifetime of the lightemitting device. Since the excited energy and charge carrier can transfer along the conjugated polymer chain, even trace amount of irregular structure is responsible for the low device reliability. One simple technique to improve device performance is the introduction of insulating segment into the conjugated main chain, which can nicely define the effective conjugation length irrespective of the chain length, terminal group, and sometimes structure defect. For the past decades, we and other groups have utilized organosilicon units as the insulating segment. ${ }^{2,3}$ Some polymers showed high fluorescence quantum yields owing to the enhancement of radiation from the singlet excited state as observed in low molecular weight materials. ${ }^{4} \mathrm{We}$ also reported that fluorene-based polymers including the tetrahedral organosilicon unit have zigzag conformation and therefore amorphous character, which contributed to the thermally stable blue-light emission in thin film. ${ }^{2 \mathrm{i}}$

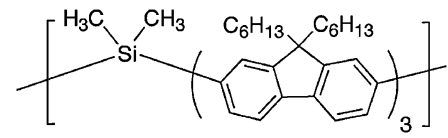

1

Figure 1. Non-conjugated polymer having terfluorene-dimethylsilylene sequence as repeating unit.

Recently, intramolecular energy transfer along a nonconjugated supramolecular system or a polymer chain has been extensively investigated because it may serve as a useful model to mimic the natural light harvesting process. ${ }^{5}$ It is known that the photoinduced through-space interaction occurs in 4-donor-4'-acceptor substituted diphenyldimethylsilanes. ${ }^{6}$ The polymer 1 (Figure 1) having terfluorene-dimethylsilylene sequence as the repeating unit emits fluorescence $\left(\lambda_{\max }=404\right.$ $\mathrm{nm}$ ) in high quantum yield (0.92) in solution, which is one of the most basic and important factor to furnish the effective energy transfer. ${ }^{7}$ Taking these facts into account, siliconbridged fluorene copolymers incorporating second chromophore (minor component) having longer effective conjugation length than terfluorene are envisaged to bring about the energy transfer ${ }^{8}$ to obtain a longer wavelength emission. The copolymers should be designed so that the absorption spectrum of energy-accepting oligoarylenevinylene chromophore can overlap with the emission spectrum of energy-donating terfluorene chromophore. Accordingly, four types of copolymers 2 (Figure 2) with various combinations of energy donor/acceptor segments were prepared and optical properties in solution and film states were investigated in order to confirm the fluorescence energy transfer. 


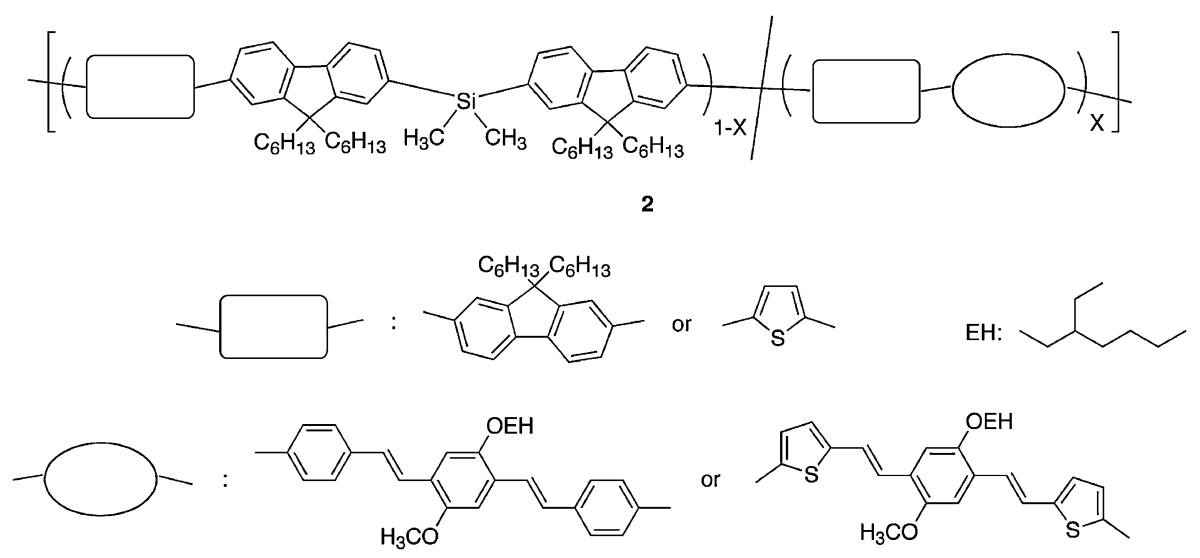

Figure 2. General chemical formula of four types of copolymers with various combinations of energy donor/acceptor segments.

\section{EXPERIMENTAL}

\section{Materials}

All reactions were performed under nitrogen. Dry tetrahydrofuran (THF) was purchased from Kanto Chemical Co. Tetrakis(triphenylphosphine)palladium $(0) \quad\left[\mathrm{Pd}\left(\mathrm{PPh}_{3}\right)_{4}\right]$ was purchased from TCI Co. 9,9-Dihexylfluorene-2,7-bis(trimethylene borate) $\mathbf{3}$ was purchased from Aldrich Chemical Co. Ethanol (EtOH) was distilled from $\mathrm{Mg}(\mathrm{OEt})_{2}$. 2,5Bis(tributylstannyl)thiophene $\mathbf{4},{ }^{9}$ bis(7,7'-dibromo-9,9, $9^{\prime}, 9^{\prime}$ tetrahexyl)fluorenyldimethylsilane $\mathbf{5},{ }^{2 \mathrm{i}}$ and 2,5-bis(triphenylphosphoniummethyl)-4-(2'-ethylhexyloxy)anisole dibromide $\mathbf{6}^{10}$ were prepared according to the literature. Other reagents were used as received.

\section{Instrumentation}

${ }^{1} \mathrm{H}$ and ${ }^{13} \mathrm{C}$ nuclear magnetic resonance (NMR) spectra were recorded on a Bruker Avance 200 FT NMR spectrometer using tetramethylsilane $\left({ }^{1} \mathrm{H} \mathrm{NMR}, \delta 0.00\right)$ or $\mathrm{CDCl}_{3}\left({ }^{13} \mathrm{C} \mathrm{NMR}, \delta\right.$ 77.0) as internal reference peaks. Infrared (IR) spectra were recorded on a Nicolet Impact 400D FT-IR spectrophotometer. Elemental analyses (EA) were performed on a Perkin Elmer PE2400II by CHN mode. Gel permeation chromatographic (GPC) analyses were carried out on a Tosoh DP-8020 using tandem TSK Multipore $\mathrm{H}_{\mathrm{XL}}-\mathrm{M}$ columns (THF as an eluent, flow rate $=1.0 \mathrm{~mL} / \mathrm{min}, 40^{\circ} \mathrm{C}$ ) equipped with the refractive index detector (RI-8010) on the basis of standard polystyrene samples. Ultraviolet (UV) spectra were recorded on a Shimadzu UV-1650PC spectrophotometer. Photoluminescence (PL) and excitation spectra were recorded on a Shimadzu RF-5300PC spectrofluorometer. The measurements were carried out using $1 \mathrm{~cm}$ quartz cell or $1 \mathrm{~cm} \times 5 \mathrm{~cm}$ quartz plate. Fluorescence quantum yields (QYs) in solution were determined relative to quinine sulfate in $0.1 \mathrm{~N} \mathrm{H}_{2} \mathrm{SO}_{4}$ with a QY of 0.55 .

\section{Monomer Synthesis}

2,5-Bis[(E)-4'-bromo- $\beta$-stylyl]-4-(2"-ethylhexyloxy)anisole 7. To $6(3.2 \mathrm{~g}, 3.2 \mathrm{mmol})$ and 4-bromobenzaldehyde $(1.2 \mathrm{~g}$,
$6.7 \mathrm{mmol})$ dissolved in $\mathrm{EtOH}(100 \mathrm{~mL})$ was added $t$-BuOK $(1.9 \mathrm{~g}, 17 \mathrm{mmol})$ in EtOH $(70 \mathrm{~mL})$ and the mixture was stirred for $65 \mathrm{~h}$ at room temperature. After filtering inorganic salts, the filtrate was concentrated to dryness, which was washed with cold $\mathrm{MeOH}$ and dried in vacuo to give pale yellow solid in $1.2 \mathrm{~g}$ (62\% yield). ${ }^{1} \mathrm{H}$ NMR (200 MHz, $\left.\mathrm{CDCl}_{3}\right) \delta$ (ppm) 7.58$7.33(10 \mathrm{H}), 7.20-6.97(4 \mathrm{H}), 4.04-3.88(5 \mathrm{H}), 1.82(\mathrm{~m}, 1 \mathrm{H})$, 1.69-1.21 (8H), 1.11-0.81 (6H). $\left.{ }^{13} \mathrm{C} \mathrm{NMR} \mathrm{(200} \mathrm{MHz,} \mathrm{CDCl}_{3}\right)$ $\delta(\mathrm{ppm}) 151.4,151.3,136.9,136.8,131.7,128.0,127.9$, 127.7, 127.6, 126.6, 126.4, 124.1, 123.9, 121.1, 121.0, 110.7, 109.6, 71.8, 56.2, 39.7, 30.9, 29.2, 24.2, 23.1, 14.1, 11.3. IR $\left(\right.$ ATR, $\left.\mathrm{cm}^{-1}\right)$ 2960, 2930, 2870, 1500, 1480, 1460, 1420, 1340, 1260, 1210, 1070, 1040, 1010, 964, 852, 808. Anal. Calcd. for: $\mathrm{C}_{31} \mathrm{H}_{34} \mathrm{Br}_{2} \mathrm{O}_{2}$ : C, 62.22; H, 5.73. Found: C, 61.89; H, 5.58.

2,5-Bis $\left[(E)-5^{\prime}\right.$-bromo-2' $\beta$-thienylenevinyl $]-4-\left(2^{\prime \prime}\right.$-ethylhexyloxy)anisole 8 . To 6 (1.2 g, $1.3 \mathrm{mmol})$ and 2-bromo-5-formylthiophene $(0.48 \mathrm{~g}, 2.5 \mathrm{mmol})$ dissolved in $\mathrm{EtOH}(40 \mathrm{~mL})$ was added $t$-BuOK $(0.67 \mathrm{~g}, 6.0 \mathrm{mmol})$ in $\mathrm{EtOH}(25 \mathrm{~mL})$ and the mixture was stirred for $23 \mathrm{~h}$ at room temperature. After filtering inorganic salts, the filtrate was concentrated to dryness, which was passed through $\mathrm{SiO}_{2}$ chromatography $\left(\mathrm{CH}_{2} \mathrm{Cl}_{2}\right.$ as an eluent). Thus obtained product was dissolved in toluene $(30 \mathrm{~mL})$ containing $\mathrm{I}_{2}(11 \mathrm{mg})$ and heated to reflux for $3 \mathrm{~h}$. The solution was washed with aq. $\mathrm{Na}_{2} \mathrm{~S}_{2} \mathrm{O}_{3}$ and evaporated to dryness. The product was purified by $\mathrm{SiO}_{2}$ chromatography (hexane:EtOAc $=10: 2$ in volume as an eluent $)(\mathrm{Rf}=0.46)$ to give brown solid in $0.35 \mathrm{~g}$ (46\% yield). ${ }^{1} \mathrm{H}$ NMR $(200 \mathrm{MHz}$, $\left.\mathrm{CDCl}_{3}\right) \delta(\mathrm{ppm}) 7.24-6.65(10 \mathrm{H}), 4.13-3.66(5 \mathrm{H}), 1.78(\mathrm{~m}$, $1 \mathrm{H}), 1.69-1.18(8 \mathrm{H}), 1.11-0.79(6 \mathrm{H}) .{ }^{13} \mathrm{C} \mathrm{NMR}(200 \mathrm{MHz}$, $\left.\mathrm{CDCl}_{3}\right) \delta(\mathrm{ppm}) 151.3,151.2,130.4,125.9,125.8,123.7$, $123.5,121.7,121.6,111.0,110.2,108.9,71.7,56.1,39.7,30.9$, 29.2, 24.2, 23.1, 14.1, 11.3. IR (ATR, $\left.\mathrm{cm}^{-1}\right)$ 2954, 2929, 2871, 1733, 1524, 1496, 1463, 1432, 1415, 1400, 1348, 1267, 1205, 1037, 951, 862, 833, 781. Anal. Calcd. for: $\mathrm{C}_{27} \mathrm{H}_{30} \mathrm{Br}_{2} \mathrm{O}_{2} \mathrm{~S}_{2}: \mathrm{C}$, 53.12; H, 4.95. Found: C, 52.93; H, 4.78.

\section{Polymerization}

2a20 (Typical Procedure). To a two-necked flask equipped with a reflux condenser containing $3(0.11 \mathrm{~g}, 0.22 \mathrm{mmol}), 5$ 


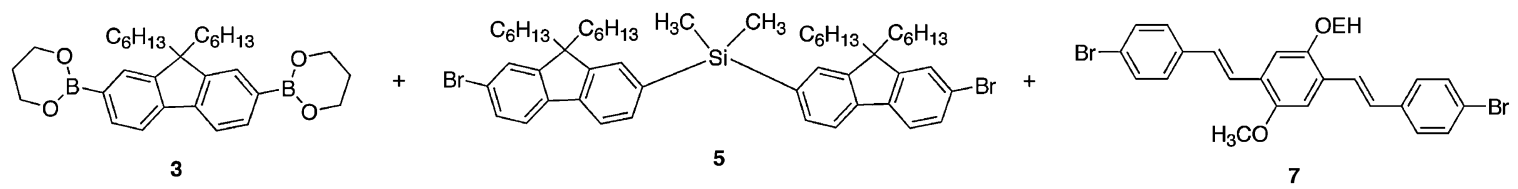

5

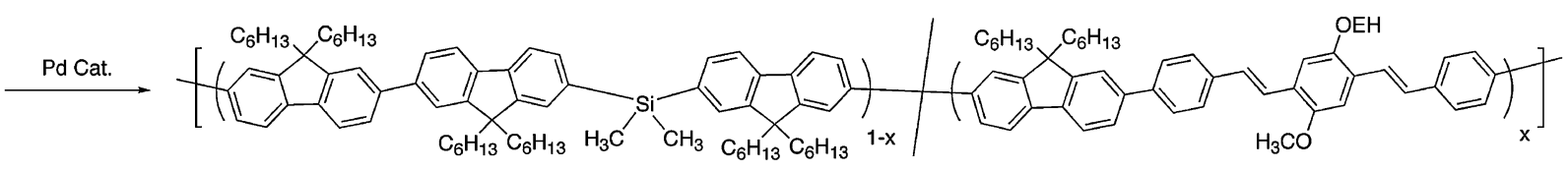

$2 \mathrm{a} 5(\mathrm{x}=0.05), 2 \mathrm{a} 10(\mathrm{x}=0.10), 2 \mathrm{a} 20(\mathrm{x}=0.20), 2 \mathrm{a} 48(\mathrm{x}=0.48)$, and $2 \mathrm{a} 100(\mathrm{x}=1)$

Scheme 1. Suzuki coupling copolymerization using 3, 5, and 7 as monomers.

$(0.14 \mathrm{~g}, 0.16 \mathrm{mmol})$, and $7(36 \mathrm{mg}, 60 \mu \mathrm{mol})$ dissolved in THF $(8 \mathrm{~mL})$ were added $2 \mathrm{M}$ aq. $\mathrm{K}_{2} \mathrm{CO}_{3}(1.3 \mathrm{~mL}, 2.6 \mathrm{mmol})$ and $\mathrm{Pd}\left(\mathrm{PPh}_{3}\right)_{4}(7.2 \mathrm{mg}, 6.2 \mu \mathrm{mol})$. The mixture was heated to reflux for $24 \mathrm{~h}$, washed with $1 \mathrm{M}$ aq. $\mathrm{HCl}$, and extracted with $\mathrm{CH}_{2} \mathrm{Cl}_{2}$. The organic phase was dried over $\mathrm{MgSO}_{4}$ and concentrated to precipitate in methanol. The obtained polymer was subjected to Soxhlet extraction with acetone and dried in vacuo at $60^{\circ} \mathrm{C}$ to give a yellow powder in $0.21 \mathrm{~g}$ (51\% yield). ${ }^{1} \mathrm{H}$ NMR $\left(200 \mathrm{MHz}, \mathrm{CDCl}_{3}\right) \delta(\mathrm{ppm})$ 8.02-7.31, 7.22-6.88 (103H), 4.07-3.94 (5H), 2.23-1.81 (58H), 1.26-0.43 (360H). IR (ATR, $\mathrm{cm}^{-1}$ ) 2952, 2927, 2852, 1490, 1460, 1411, 1263, 1212, 1037, 966,812 . Other polymerizations were likewise performed using $3,4,5,7$, and 8 in combination and their structure were confirmed by ${ }^{1} \mathrm{H}$ NMR and IR spectra.

2 b13 (brown powder). ${ }^{1} \mathrm{H} \mathrm{NMR}\left(200 \mathrm{MHz}, \mathrm{CDCl}_{3}\right) \delta$ (ppm) $7.82-7.30, \quad 7.24-6.88$ (158H), 4.02-3.90 (5H), 2.22-1.83 (94H), 1.29-0.53 (592H). IR (ATR, $\left.\mathrm{cm}^{-1}\right)$ 2963, 2929, 2857, 2364, 2345, 1458, 1418, 1260, 1020, 798.

$2 \mathrm{c11}$ (yellow powder). ${ }^{1} \mathrm{H} \mathrm{NMR}\left(200 \mathrm{MHz}, \mathrm{CDCl}_{3}\right) \delta(\mathrm{ppm})$ $7.79-7.28, \quad 7.24-7.07 \quad(127 \mathrm{H}), \quad 4.03-3.93 \quad(5 \mathrm{H}), \quad 2.12-1.83$ $(54 \mathrm{H}), 1.28-0.48(382 \mathrm{H})$. IR (ATR, $\left.\mathrm{cm}^{-1}\right)$ 2956, 2928, 2857, 1605, 1464, 1263, 1092, 1038, 819, 797, 694.

$2 d 3$ (reddish orange powder). ${ }^{1} \mathrm{H} \mathrm{NMR}\left(200 \mathrm{MHz}, \mathrm{CDCl}_{3}\right) \delta$ (ppm) 7.80-7.28, 7.21-6.03 (239H), 3.99-3.83 (5H), 2.19-1.81 (133H), 1.28-0.51 (808H). IR (ATR, $\left.\mathrm{cm}^{-1}\right)$ 2957, 2928, 2857, 1607, 1463, 1262, 1216, 1092, 1023, 797, 689.

\section{RESULTS AND DISCUSSION}

\section{Preparation}

Dibromo monomers $\mathbf{7}$ and $\mathbf{8}$ were synthesized by the Wittig reaction. Since the NMR and IR spectra of initial product obtained by the reaction of 6 with 2-bromo-5-formylthiophene suggested a mixture of $E / Z$ isomer, the transformation from $Z$ to $E$ isomer was carried out by catalytic amount of $\mathrm{I}_{2}$ in refluxed toluene. Polymers (2a5, 2a10, 2a20, 2a48, and 2a100) with various concentration of oligoarylenevinylene segment were subsequently obtained by the Suzuki coupling copolymerization using 3, 5, and $\mathbf{7}$ as monomers (Scheme 1). The $\mathbf{x}$ value was calculated by comparing the integral ratio of methyl and methylene proton signals adjacent to the oxygen of alkoxy substituents observed at approximately $4 \mathrm{ppm}$ with those of
Table I. Characterization of copolymers with various oligoarylenevinylene segments

\begin{tabular}{cccccc}
\hline Code & Yield (\%) & $M_{\mathrm{n}}{ }^{\mathrm{b}}$ & $M_{\mathrm{w}} / M_{\mathrm{n}}{ }^{\mathrm{b}}$ & Theoretical x & Calculated $\mathrm{x}^{\mathrm{c}}$ \\
\hline 2a5 & 47 & 9700 & 2.0 & 0.05 & 0.05 \\
2a10 & 39 & 11800 & 1.7 & 0.10 & 0.10 \\
2a20 & 51 & 12100 & 2.2 & 0.20 & 0.20 \\
2a48 & 50 & 16900 & 2.3 & 0.50 & 0.48 \\
2a100 & 38 & 16100 & 2.7 & 1.0 & $(1.0)$ \\
\hline 2b13 & 32 & 8800 & 1.6 & 0.10 & 0.13 \\
\hdashline 2c11 & 38 & 8300 & 2.0 & 0.15 & 0.11 \\
\hdashline 2d3 & 31 & 6700 & 1.7 & 0.05 & 0.03 \\
\hline
\end{tabular}

${ }^{a}$ Isolated yield after precipitation into $\mathrm{MeOH}$ and Soxhlet extraction with acetone. ${ }^{b}$ Estimated by GPC (THF, PSt standard). ${ }^{\mathrm{c}}$ Calculated from ${ }^{1} \mathrm{H}$ NMR spectrum.

aromatic proton signals or methylene proton signals adjacent to the carbon at 9-position of fluorine observed at around $2 \mathrm{ppm}$ in the ${ }^{1} \mathrm{H}$ NMR spectrum (Table I). If 5 has much higher reactivity than 7 (or vice versa) in the coupling reaction with $\mathbf{3}$, two bromo functionalities may react with $\mathbf{3}$ to give new bis(trimethylene borate) species which slowly reacts with remaining 7 (or 5) to force terfluorene and oligoarylenevinylene segments to be alternatively arranged, especially for $\mathbf{2 a 4 8}$ having these two segments in the equivalent ratio. Judging from the ${ }^{13} \mathrm{C}$ chemical shift of carbon substituted by the bromine, however, 5 (121.6 ppm) and 7 (121.1 ppm) are supposed to have comparable reactivity toward the oxidative addition of zero valent palladium species. Accordingly, the coupling reaction of $\mathbf{5}$ and $\mathbf{7}$ with $\mathbf{3}$ equally takes place at the initial stage of polymerization to give a chance for these two segments to consecutively connect to afford so-called segment block copolymer though the accurate sequence cannot be determined. The number averaged molecular weight ranged from 9700 to 17000 and the polydispersity indices were around 2. All polymers were readily soluble in organic solvents such as toluene, $\mathrm{CHCl}_{3}$, and THF thanks to the zigzag main chain arisen from the tetrahedral organosilicon unit. Likewise, $\mathbf{2 b 1 3}$, 2c11, and 2d3 were prepared by the Suzuki and Stille coupling copolymerization using $\mathbf{3}, \mathbf{4}, \mathbf{5}, \mathbf{7}$, and $\mathbf{8}$ in combination and the molar ratio $\mathbf{x}$ could be nearly controlled by the monomer feed ratio (Figure 3). 


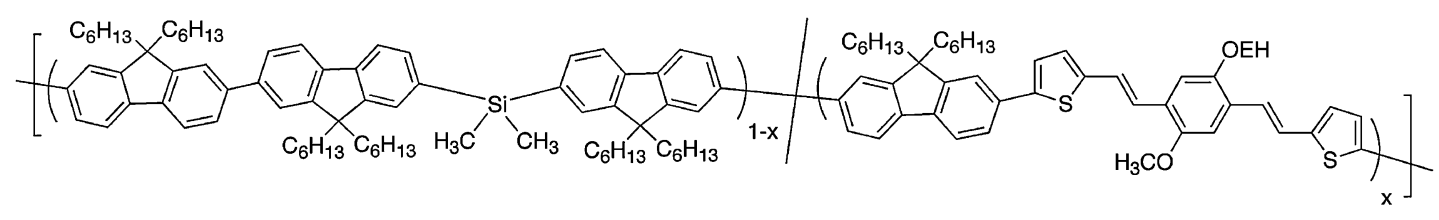

$2 b 13(x=0.13)$

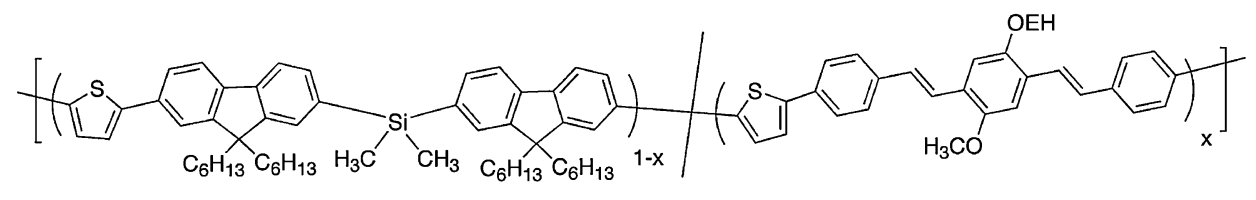

$2 c 11(x=0.11)$

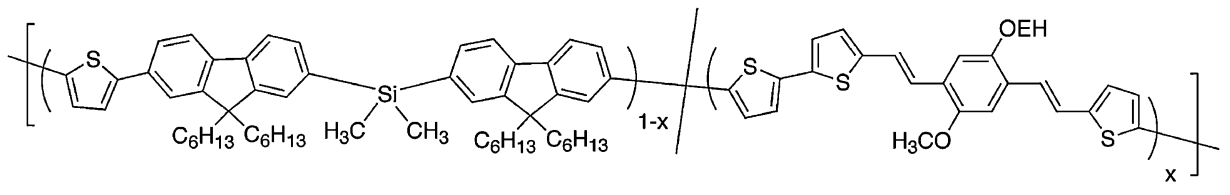

$2 \mathrm{~d} 3(x=0.03)$

Figure 3. Chemical formula of $2 b 13,2 c 11$, and $2 d 3$.

\section{Optical Properties}

The UV and PL spectra of polymers were collected in $\mathrm{CHCl}_{3}$ under the concentration of $10^{-6} \mathrm{M}$ per average molecular weight of two kinds of repeating unit. By the increment of oligoarylenevinylene segment, the absorption maximum peak of terfluorene at $358 \mathrm{~nm}$ decreased and that of oligoarylenevinylene at $420 \mathrm{~nm}$ increased (Figure 4a). The observation of an isosbestic point at $387 \mathrm{~nm}$ indicates that the oligoarylenevinylene chromophore could be introduced in the polymer chain as intended. The emission maximum peak was observed at $401 \mathrm{~nm}$ with the vibronic fine structure at $422 \mathrm{~nm}$ in $\mathbf{1}$, which gradually decreased as the total amount of terfluorene that absorb the excitation light at $358 \mathrm{~nm}$ in the polymer chain diminished (Figure 4b). Meanwhile, the fluorescence at $477 \mathrm{~nm}$ became prominent with concomitant decrease of quantum yield which dropped from 0.92 (1) to 0.54 (2a48). The fluorescence color varied from blue (1) to green (2a48) in naked eye. It is a matter of importance that the intensities of fluorescence at $401 \mathrm{~nm}$ and $477 \mathrm{~nm}$ are comparable in $\mathbf{2 a 1 0}$, however, only the fluorescence at $401 \mathrm{~nm}$ is detected when $\mathbf{1}$ and $\mathbf{2 a 1 0 0}$ are blended in the molar ratio of 9:1 to keep the content of oligoarylenevinylene segment as same as that in $\mathbf{2 a 1 0}$ (polymer blend system) (Figure 5a). These results strongly support that the energy transfer from the energy-donating terfluorene to the energy-accepting oligoarylenevinylene occurs "within a single polymer chain" in dilute solution. Furthermore, the energy transfer behavior of $\mathbf{2 a 1 0}$ and the polymer blend system was different in thin film obtained by spin-coating a toluene solution of polymer under the condition of $500 \mathrm{rpm}$ for $5 \mathrm{~s}$ and then $2000 \mathrm{rpm}$ for $60 \mathrm{~s}$. The fluorescence of oligoarylenevinylene chromophore at $481 \mathrm{~nm}$ with the vibronic fine structure at $510 \mathrm{~nm}$ was solely observed in $\mathbf{2 a 1 0}$. On the contrary, the nonnegligible shoulder peak at $414 \mathrm{~nm}$ arisen from terfluorene chromophore was detected in the polymer blend system
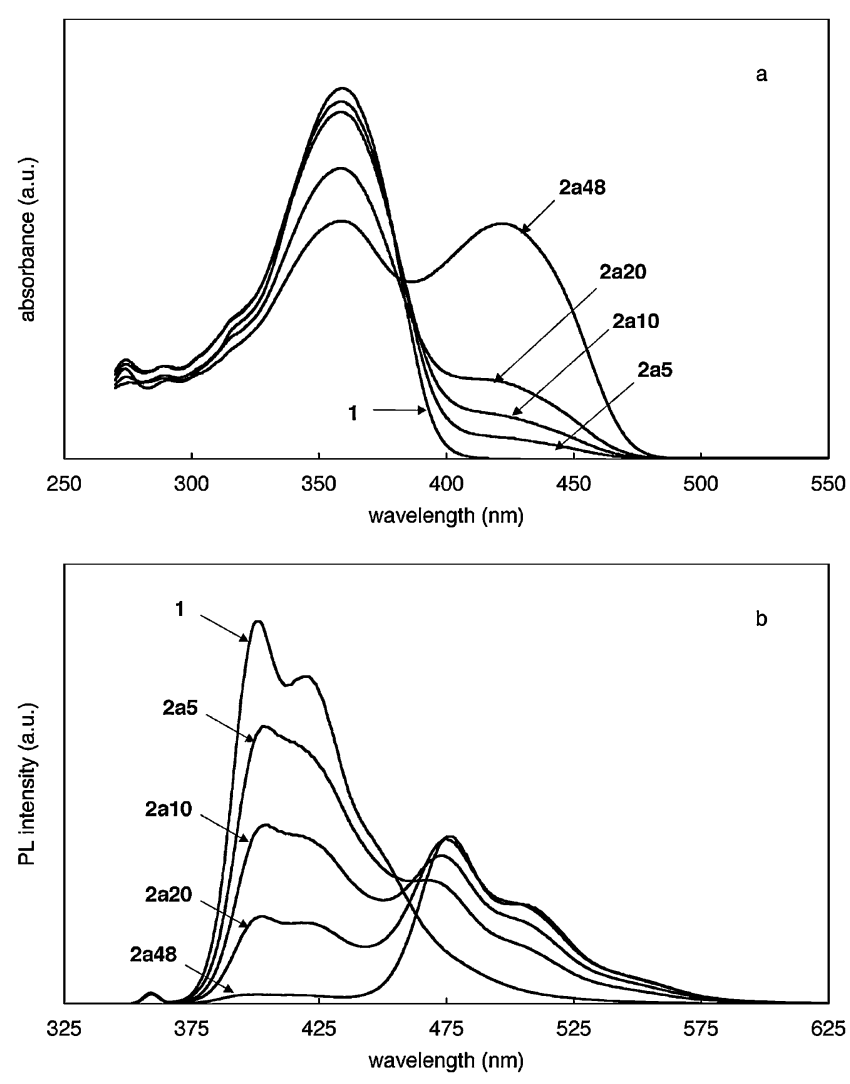

Figure 4. UV (a) and PL (b) spectra of polymers (1, 2a5, 2a10, 2a20, and 2a48) in $\mathrm{CHCl}_{3}$.

(Figure 5b), although polymer chains were present in close proximity each other to enable through space energy transfer in thin film. Accordingly, not only the inter-polymer chain but also the intra-polymer chain interaction of chromophores is 

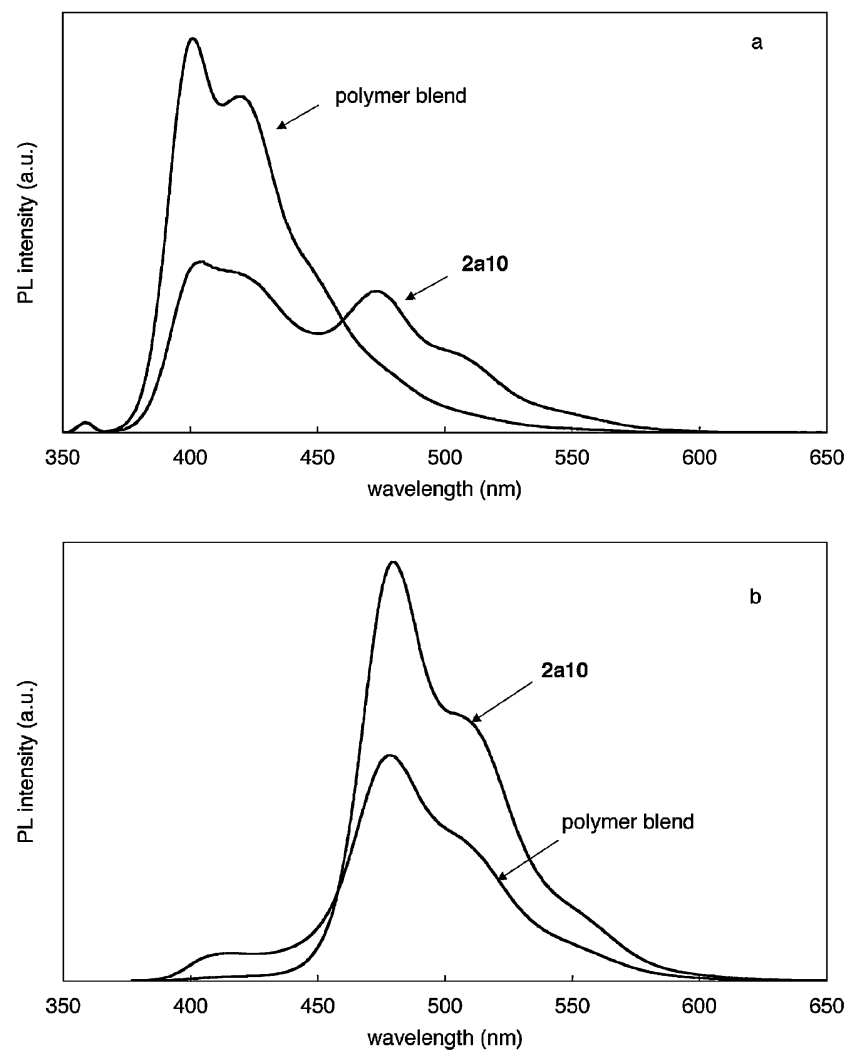

Figure 5. $\mathrm{PL}$ spectra of $2 \mathrm{a} 10$ and polymer blend $(\mathbf{1 : 2 \mathrm { a } 1 0 0}=9: 1)$ in (a) $\mathrm{CHCl}_{3}$ and (b) thin film

indispensable for the effective energy transfer, which may occur incompletely in the polymer blend system. According to the method by Luh et al., ${ }^{8 b}$ the absorption spectrum of $\mathbf{2 a 4 8}$ was compared with the excitation spectrum monitored at $477 \mathrm{~nm}$, where two spectra are normalized at the maximum wavelength of the energy-donating terfluorene $(420 \mathrm{~nm})$. The efficiency of energy transfer was estimated to be $66 \%$. This value is much lower than materials having alternatively arranged sequence of energy-donor and energy-acceptor separated by the dimethylsilylene unit (87\%). Since $\mathbf{2 a 4 8}$ may have a segment block character as mentioned above, the excited energy of terfluorene cannot be efficiently transferred to the oligoarylenevinylene chromophore.

Finally, the UV and PL spectra of $\mathbf{2 b 1 3}, \mathbf{2 c 1 1}$, and $\mathbf{2 d 3}$ were measured in thin film. The absorption maxima were observed at $363 \mathrm{~nm}$ for $\mathbf{2 b 1 3}$ bearing terfluorene and at $393 \mathrm{~nm}$ for $\mathbf{2 c 1 1}$ and $\mathbf{2} \mathbf{d} 3$ bearing bifluorenylthiophene as the major component, as found in $\mathrm{CHCl}_{3}$ solution. The fluorescence peak was detected at $535 \mathrm{~nm}, 517 \mathrm{~nm}$, and $570 \mathrm{~nm}$ for 2b13, 2c11, and $\mathbf{2 d 3}$, respectively, which ascribed to the emission from oligoarylenevinylene chromophore included in the polymer chain as the minor component (Figure 6). It is conceivable that the intra- and inter-polymer chain energy transfers bring about to harvest the excited energy of terfluorene or bifluorenylthiophene toward oligoarylenevinylene chromophore having the longer effective conjugation length.

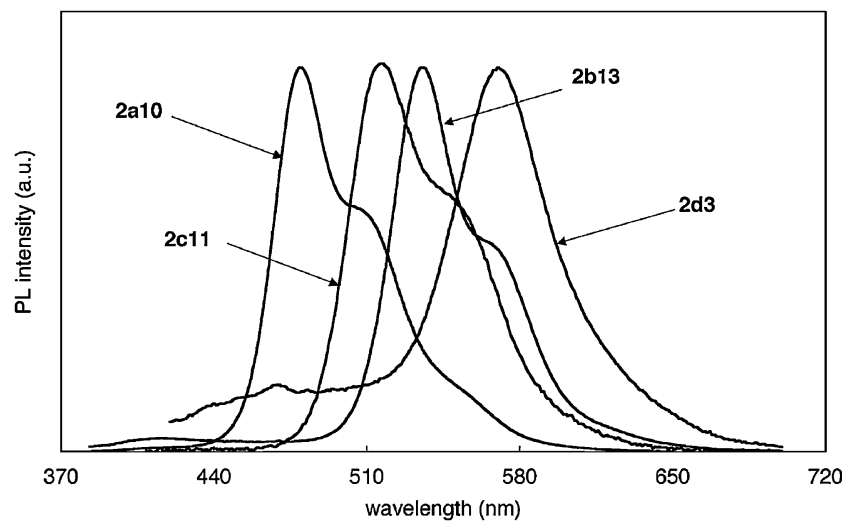

Figure 6. PL spectra of $2 a 10,2 b 13,2 c 11$, and $2 d 3$ in thin film.

Received: April 15, 2009

Accepted: May 26, 2009

Published: July 9, 2009

\section{REFERENCES}

1. a) A. Yokoyama, R. Miyakoshi, and T. Yokozawa, Macromolecules, 37, 1169 (2004).

b) R. Miyakoshi, A. Yokoyama, and T. Yokozawa, Macromol. Rapid Commun., 25, 1663 (2004).

c) R. Miyakoshi, A. Yokoyama, and T. Yokozawa, J. Am. Chem. Soc., 127, 17542 (2005).

d) E. E. Sheina, J. Liu, M. C. Iovu, D. W. Laird, and R. D. McCullough, Macromolecules, 37, 3526 (2004).

e) M. C. Iovu, E. E. Sheina, R. R. Gil, and R. D. McCullough, Macromolecules, 38, 8649 (2005).

f) M. Jeffries-El, G. Sauvé, and R. D. McCullough, Macromolecules, 38, 10346 (2005).

2. a) R.-M. Chen, K.-M. Chien, K.-T. Wong, B.-Y. Jin, and T.-Y. Luh, J. Am. Chem. Soc., 119, 11321 (1997).

b) Y.-J. Miao and G. C. Bazan, Macromolecules, 30, 7414 (1997).

c) H. Li and R. West, Macromolecules, 31, 2866 (1998).

d) D. S. Kim and S. C. Shim, J. Polym. Sci., Part A: Polym. Chem., 37, 2263 (1999).

e) S. H. Jung, H. K. Kim, S. H. Kim, Y. H. Kim, S. C. Jeoung, and D. Kim, Macromolecules, 33, 9277 (2000).

f) A. Mori, E. Takehisa, H. Kajiro, Y. Nishihara, and T. Hiyama, Macromolecules, 33, 1115 (2000).

g) J. Ohshita, A. Takata, H. Kai, A. Kunai, K. Komaguchi, M. Shiotani, A. Adachi, K. Sakamaki, K. Okita, Y. Harima, Y. Kunugi,

K. Yamashita, and M. Ishikawa, Organometallics, 19, 4492 (2000).

h) X. Jiang, Y. Harima, K. Yamashita, A. Naka, K. K. Lee, and M. Ishikawa, J. Mater. Chem., 13, 785 (2003).

i) K. Takagi, H. Kakiuchi, and M. Suzuki, Kobunshi Ronbunshu, 63, 663 (2006).

j) K. Takagi, H. Kakiuchi, Y. Yuki, and M. Suzuki, J. Polym. Sci., Part A: Polym. Chem., 45, 4786 (2007).

k) X.-H. Zhou, Y.-H. Niu, F. Huang, M. S. Liu, and A. K.-Y. Jen, Macromolecules, 40, 3015 (2007).

3. For a polymer containing silole segment, see: K. L. Chan, M. J. McKiernan, C. R. Towns, and A. B. Holmes, J. Am. Chem. Soc., 127, 7662 (2005).

4. a) S. Kyushin, M. Ikarugi, M. Goto, H. Hiratsuka, and H. Matsumoto, Organometallics, 15, 1067 (1996).

b) H. Maeda, Y. Inoue, H. Ishida, and K. Mizuno, Chem. Lett., 30, 1224 (2001).

c) S. Yamaguchi and K. Tamao, J. Chem. Soc., Dalton Trans., 3693, 
1998.

d) S. Yamaguchi and K. Tamao, J. Organomet. Chem., 653, 223 (2002).

5. a) S. E. Webber, Chem. Rev., 90, 1469 (1990).

b) A. Adronov, S. L. Gilat, J. M. J. Fréchet, K. Ohta, F. V. R. Neuwahl, and G. R. Fleming, J. Am. Chem. Soc., 122, 1175 (2000). c) M. A. Fox, Acc. Chem. Res., 32, 201 (1999).

d) C. Devadoss, P. Bharathi, and J. S. Moore, J. Am. Chem. Soc., 118, 9635 (1996).

e) J. M. Serin, D. W. Brousmiche, and J. M. J. Fréchet, Chem. Commun., 2002, 2605.

f) C. Hippius, F. Schlosser, M. O. Vysotsky, V. Böhmer, and F. Würthner, J. Am. Chem. Soc., 128, 3870 (2006).

6. a) C. A. van Walree, M. R. P. Roest, W. Schuddeboom, L. W.
Jenneskens, J. W. Verhoeven, J. M. Warman, H. Kooijman, and A. L. Spek, J. Am. Chem. Soc., 118, 8395 (1996).

b) A. Zehnacker, F. Lahmani, C. A. Van Walree, and L. W. Jenneskens, J. Phys. Chem. A, 104, 1377 (2000).

7. T. Förster, Ann. Phys., 437, 55 (1948).

8. a) Y.-J. Cheng, T.-Y. Hwu, J.-H. Hsu, and T.-Y. Luh, Chem. Commun., 1978, (2002).

b) Y.-J. Cheng and T.-Y. Luh, Chem.-Eur. J., 10, 5361 (2004).

c) Y.-J. Cheng, S. Basu, S.-J. Luo, and T.-Y. Luh, Macromolecules, 38, 1442 (2005).

9. W. You, S. Cao, Z. Hou, and L. Yu, Macromolecules, 36, 7014 (2003).

10. T. Ahn, S.-Y. Song, and H.-K. Shim, Macromolecules, 33, 6764 (2000). 